\title{
As sementes transgênicas no Brasil: da proibição à liberação
}

Patrícia Faraco Benthien'

"Quando Tony Blair e Bill Clinton
anunciaram que o mapa do
genoma humano estava completo,
não havia nem mais um pedacinho de
nossa 'humanidade que a Indistria
da Vida não tivesse se apropriado".?

Resumo: $\mathrm{O}$ presente artigo consiste em uma tentativa de elucidação social e observação crítica sobre a temática dos organismos geneticamente modificados (OGM ou transgênicos) no Brasil durante os governos Fernando Henrique Cardoso e Luis Inácio Lula da Silva, já que durante estes ocorreram situações marcantes no tocante à inserção de sementes transgênicas no país. Dentre estas situações se destacam a atuação da Comissão Técnica Nacional de Biossegurança (CTNBio) e a edição de duas medidas provisórias $\left(\mathrm{n}^{\circ} 113\right.$ e 131) bastante polêmicas. Neste período também é relevante a atuação constante de organizações da. sociedade civil e ONGs no intuito de conscientização e oposição a determinadas atitudes do governo.

Palavras-chave: transgênicos, CTNBio, transnacionais, Monsanto, Terminator.

\section{Introdução:}

A transgenia na agricultura representa um grande interesse econômico vinculado à apropriação tecnológica no mundo. Tendo em vista a grande polêmica nacional e internacional que envolve questão da transgenia como um processo já instaurado mundialmente, além de aceito em muitos paises, pretendo através do presente artigo esclarecer a polêmica de forma mais localizada, isto é, traçar uma perspectiva histórica e crítica sobre a inserção de sementes transgênicas no Brasil a partir do governo Fernando Henrique Cardoso (apesar da existência de transgenia agrícola no

\footnotetext{
Graduada em Relações Internacionais e mestranda do Programa de Pós-Graduação em Sociologia da UFPR. Bolsista da CAPES.

${ }^{2}$ Mooney, Pat Roy. O Século 21: Erosão, Transformação Tecnológica e Concentração do Poder Empresarial. São Paulo: Expressão Popular, 2002, p.144.
} 
país desde o final da década de 70) e que persiste até a atualidade. Desta forma tentar-se-á caracterizar este processo como um instrumento da racionalidade econômica global representada pelos grandes conglomerados internacionais produtores de sementes transgênicas.

Este artigo divide-se em três tópicos. O primeiro tópico consiste em um breve histórico da engenharia genética até a concretização da tecnologia de DNA recombinante, que possibilitou o processo que atualmente é conhecido como transgenia ou transgênese. Este tópico tem o intuito de esclarecer o que realmente é a transgenia; já que, mesmo no circuito universitário, várias dúvidas são suscitadas a respeito do tema. Há a necessidade a priori de uma diferenciação conceitual sobre o que vem a ser melhoramento genético e transgenia, para que seja possível a visualização da problemática que envolve a criação e inserção de transgênicos principalmente na agricultura.

O segundo tópico trata especificamente da situação brasileira frente à polêmica das sementes transgênicas a partir do Governo Fernando Henrique Cardoso no qual a atuação de uma comissão denominada Comissão Técnica Nacional de Biossegurança (CTNBio), foi grande influenciadora da implementação de transgênicos dentro do território nacional. Este tópico também versa sobre o contrabando de transgênicos do território argentino realizado pela fronteira com o Rio Grande do Sul no mesmo período.

O terceiro tópico consiste principalmente no primeiro e segundo anos do Governo Lula nos quais foram decretadas duas medidas provisórias bastante contestadas pela sociedade civil organizada que liberaram o plantio de transgênicos em território nacional. Este período representa a indireta aceitação da transgenia no país além de demonstrar uma flexibilização por parte do governo federal inesperada e condenada pelos movimentos ambientalistas.

\section{I - Um breve histórico do desenvolvimento da engenharia genética:}

$\mathrm{O}$ que atualmente se conhece como biotecnologia, que se trata da manipulação a nível celular dos seres vivos através da combinação de vários campos científicos e tecnológicos distintos (Mairesse, 2001), tem seus primórdios datados do final do século XIX e início do século XX, quando o frade austríaco Gregor Mendel, através de suas experiências com hibridação de plantas, cria a teoria da hereditariedade que foi reconhecida como uma 
lei da biologia apenas 16 anos após seu falecimento ${ }^{3}$. Esta teoria foi definidora da forma de ocorrência da transmissão hereditária entre gerações de espécies. É neste mesmo período que conceitos como $\mathrm{DNA}^{4}$ e cromossomo são popularizados.

Cerca de meio século depois, no ano de 1962, o cientista britânico Francis Crick e o norte-americano James Watson descobrem a existência de uma hélice dupla no DNA, que de fato seria a impulsionadora de grandes descobertas científicas no futuro. Foi exatamente através da descoberta da hélice dupla que tornou possível a visualização da capacidade e, conseqüentemente, do processo de duplicação do DNA.

O próximo passo realizado após a percepção da capacidade e do processo de duplicação do DNA foi a tentativa de interferência no código genético. Esta se concretiza na medida em que dois cientistas norteamericanos, Stanley Cohen e Herbert Boyer, descobrem a capacidade de recombinação do $\mathrm{DNA}^{5}$. Foi a partir de suas pesquisas que se comprovou a semelhança da estrutura genética entre seres de diferentes espécies ${ }^{6}$. Desta forma, o diferencial entre os seres é, na realidade, a distribuição dos genes no DNA. Comprovou-se então que, dada a semelhança da estrutura genética de seres distintos, havia a possibilidade de mapeamento, codificação e interferência no código genético dos seres vivos.

A concretização do que atualmente denominamos engenharia genética torna-se uma realidade na medida em que a recombinação gênica explicita a semelhança genética entre as espécies e permite, por conseguinte, a possibilidade de remoção ou implantação de genes rompendo a barreira entre as espécies: "A engenharia genética ultrapassa as barreiras das espécies. Com essa nova tecnologia, a manipulação ocorre no nível genético e não no nível da espécie. A unidade de trabalho não é mais o

\footnotetext{
3 "Mesmo tendo tido a ousadia de juntar a biologia e a matemática e de ter descoberto as leis fundamentais da hereditariedade, que funcionam para todos os seres vivos, Mendel, com seu trabalho, não chamou muita atenção. Em fevereiro de 1895, ele foi até a Sociedade de História Natural de Brünn na certeza de que ficaria famoso por ter desvendado o mistério. da hereditariedade. O público presente em sua palestra, que esperava um debate sobre plantas, acabou tendo uma explanação matemática sobre hereditariedade e retirou-se sem demonstrar nenhum entusiasmo". (Aragão, 2003, p.05)

${ }^{4}$ Ácido desoxirribonucléico.

5 A capacidade de recombinação gênica confirma o código genético como universal e possibilita a introdução e troca de genes entre espécies, mesmo entre espécies diferentes.

${ }^{6}$ É incrivel a semelhança genética entre espécies diferentes, o homem o macaco possuem mais de $90 \%$ da estrutura genética igual.
} 
organismo, e sim o gene. As implicações são enormes e de longo alcance". (Rifkin, 1999, p.14)

Jeremy Rifkin (1999) fornece um exemplo bastante ilustrativo da atuação da engenharia genética sobre diferentes espécies quando relata que, em 1983 na Pensilvânia, houve a inserção de genes humanos em embriões de ratos. Tal transferência genética teve como resultado o crescimento duas vezes mais rápido dos ratos do que o normal, entretanto não foi espantosa apenas a velocidade de crescimento, mas também o tamanho dos ratos, que igualmente duplicou.

Neste ponto vale ressaltar a diferença entre melhoramento genético e transgenia, já que estes constituem conceitos bastante distintos. O melhoramento genético iniciou-se com agricultores que, pela vivência de suas práticas agrícolas e pelos saberes tradicionais e cultura locais, começaram a perceber que determinados tipos de sementes eram mais adaptáveis a suas terras que outras e, desta forma, realizaram cruzamentos de sementes para torná-las mais produtivas e resistentes em atenção às suas necessidades. Este tipo de melhoramento genético também é realizado em laboratório. A natureza, independente da ação humana, tem a capacidade de registrar tais alterações e realizar tais modificações, entretanto o homem, através de seus saberes, comandou tais processos em seu favorecimento.

A transgenia consiste em um processo realizado apenas em laboratório, isto é, a natureza por si só nunca seria capaz de constituir um transgênico já que não consegue cruzar e conceber modificações entre espécies diferentes. A transgenia não consiste, portanto, em um avanço no processo de evolução, como salienta Araújo (2001, p.07):

Provavelmente uma das maiores falácias apresentadas por alguns dos defensores dos produtos transgênicos seja a que tenta confundir o público com a idéia de que transgenia seria algo ocorrente na natureza, sendo a intervenção humana apenas destinada a propiciar um "atalho" no processo de evolução, uma forma mais rápida do que aconteceria por processos naturais. Tenta-se difundir a idéia de que os processos decorrentes da engenharia genética nada mais são do que um passo a mais no curso da milenar seleção das espécies e dos métodos convencionais de melhoramento vegetal e animal.

Rifkin (1999) considera o século em que vivemos como "O Século da Biotecnologia" com bastante razão. A transgenia, ao integrar uma transformação genética através de uma tecnologia, torna possíveis criações 
que atendam a determinados interesses ${ }^{8}$, e por isso, todo o produto que é criado através de um processo de transgenia, tem a possibilidade de ser patenteado, ou seja, tem dono.

Tendo em vista este grande avanço da ciência, os conglomerados multinacionais do setor bioquímico e farmacêutico começaram a visualizar na transgenia uma fonte bastante promissora de lucros futuros já que percebem que, se aplicassem a transgenia na agricultura especificamente, poderiam criar sementes nunca antes vistas e despertar os interesses de agricultores, além de conseguirem uma grande vantagem comercial através das leis de patentes que foram definidas na Rodada do Uruguai do GATT ${ }^{9}$ implementada em 1995. Nesta negociação foi estabelecido que todos os Estados membros da OMC deveriam respeitar as leis de patente que implicam no patenteamento de "(...) toda invenção, de produto ou procedimento, em todos os domínios tecnológicos, sob a condição de que seja nova, que implique uma atividade inventiva e que seja suscetível de aplicação industrial. Inclusive todas aquelas referentes ao ser vivo". (Perrière e Seuret, 2001, p.110) Desta forma, o direito de patentes começa a envolver a vida, desde que esta seja fruto da inventividade humana.

Pelaez e Schmidt (2000) caracterizam a década de 90 como um período definido pela "mobilidade de capitais", de empresas do ramo farmacêutico e químico para o ramo das sementes, em detrimento da criação de transgênicos destinados à agricultura. Não é espantoso, portanto, que atualmente apenas cinco empresas dominem o mercado de sementes mundiais:

\begin{abstract}
Atualmente cinco empresas controlam quase a totalidade da produção de sementes transgênicas no mundo (Monsanto, Novartis, Astra Zeneca, Aventis e Du Pont). A Monsanto tornou-se a pioneira neste segmento de mercado ao desenvolver uma linha de sementes transgênicas, com destaque para a Roundup Ready, uma semente de soja com maior resistência ao produto da empresa o herbicida Roundup. (Pelaez e Schmidt, 2000, p.05)
\end{abstract}

\footnotetext{
${ }^{8}$ Os interesses aos quais me refiro podem ser de várias ordens, desde a criação em vista das necessidades (ou das necessidades criadas) humanas, ou mesmo em vista aos interesses de venda das grandes empresas transnacionais.

${ }^{9} \mathrm{O}$ GATT (General Agreement on Tariffs and Trade) foi o prelúdio da criação da OMC (Organização Mundial do Comércio).
} 
Atualmente, as sementes transgênicas existentes no mercado, que compreendem sementes de soja, milho, algodão e canola, são de dois tipos principais: o primeiro tipo são sementes que possuem um mecanismo de resistência a herbicidas, como é o caso da semente de soja Roundup Ready ${ }^{10}$ da Monsanto; o segundo compreende plantas inseticidas, isto é, aquelas que, ao terem uma folha comida por um inseto, funcionam como um veneno matando-o. As sementes "Bt", também produzidas pela Monsanto, apresentam-se como o exemplo mais conhecido deste tipo de semente transgênica. Segundo Londres (2002) os transgênicos resistentes a herbicidas cultivados no mundo representam $74 \%$ do total. Outros $19 \%$ são dos cultivos com propriedades "inseticidas" e os 7\% restantes são combinação destas duas características.

Outro tipo de semente transgênica criada, mas que atualmente foi retirada do mercado pela grande polêmica que causou, é a semente da Monsanto chamada Terminator. Esta tecnologia, patenteada em 1998 pela empresa, se caracteriza pela criação de sementes que, em sua segunda geração, são estéreis. A idéia da esterilidade da semente está vinculada com a permissão de cobrança de royalties por parte das empresas multinacionais produtoras de transgênicos dado o direito de patentes sobre as sementes. De acordo com as leis que regem o direito de patentes, os agricultores que comprarem sementes transgênicas assinam um contrato no qual assumem que não replantarão as sementes oriundas de sua plantação na próxima safra como o fazem com as sementes convencionais, tendo que, obrigatoriamente, comprar novas sementes para a safra seguinte.

A tecnologia Terminator, portanto, é um grande facilitador da fiscalização para as multinacionais já que as empresas mantêm geralmente fiscais percorrendo as plantações para perceber se não há a quebra dos contratos por parte dos agricultores". Nos países mais pobres as

\footnotetext{
${ }^{10}$ A semente de soja Roundup é resistente ao glifosato que se trata de um produto que os agricultores chamam de "mata-mato". Logo, quando este produto é espalhado na plantação, acaba com mato que rodeia a soja e apenas esta sobrevive ao produto.

${ }^{11}$ A Monsanto já processou vários agricultores que supostamente estariam plantando sementes transgênicas sem o pagamento de royalties. O caso mais conhecido é do agricultor canadense Pery Schmeiser processado pela empresa em 1998 por plantar ilegalmente canola transgênica. Este agricultor esteve em 2003 no Fórum Social Mundial em Porto Alegre para dar seu depoimento a respeito do processo e afirmou que nunca plantou transgênicos, entretanto sua plantação estava contaminada. Ao analisar os nível de contaminação de transgênicos em sua plantação, percebeu que as áreas limítrofes às plantações de seus vizinhos eram as que estavam mais contaminadas. Posteriormente descobriu que seu vizinho estava plantando canola
} 
dificuldades de acesso às lavouras são grandes. Logo, esta tecnologia além de poupar mão-de-obra dispensaria o contrato, como salientam Perrière e Seuret (1999):

Esta tecnologia só é vantajosa para as multinacionais que não precisarão mais preocupar-se em fazer o camponês assinar um contrato comprometendo-se a não replantar as sementes colhidas. A esterilidade contratual perde o sentido diante da esterilidade biológica, muito mais eficaz. Especialmente nos paises do Sul, onde a falta de estrutura torna muito mais dificeis as ações judiciais, mas o mercado em potencial é gigantesco. Calcula-se que mais de três quartos das sementes utilizadas provêm da safra anterior. É claro que os camponeses não estariam obrigados a comprar essas novas sementes estéreis, mas algumas ONGs temem que eles sejam insistentemente incitados nesse sentido, entrando assim num espiral de custos, endividamento e dependência. (Perrière e Seuret, 1999, p.57)

É interessante notar que as décadas de 80 e 90 foram caracterizadas por um movimento bastante acentuado de aquisições e fusões que repercute na formação de oligopólios mundiais (Chesnais, 1997). Tal situação é perceptível quando levamos em consideração a oferta de sementes no mundo: a Monsanto é fornecedora de sementes para cerca de $80 \%$ da área plantada em todo mundo, em segundo lugar encontra-se a empresa Aventis que tem suas vendas representadas por $7 \%$ de áreas plantadas com suas sementes (Araújo, 2003). Segundo palestra apresentada por João Pedro Stédile ${ }^{12}$ atualmente dez grandes empresas são responsáveis por $90 \%$ dos agrotóxicos vendidos no mundo, assim como de 58\% dos produtos farmacêuticos; estas empresas controlam $30 \%$ da produção de alimentos, $30 \%$ do mercado de sementes e, deste mercado, dominam $90 \%$ das sementes de soja, milho, trigo e cacau vendidas mundialmente.

Segundo as informações fornecidas por Stédile, a quantidade de variedades vegetais existentes no mundo diminuiu drasticamente gerando uma planificação alimentar. Este relata que até o ano de 1500 existiam três mil variedades vegetais; quatrocentos e cinqüenta anos depois o número de variedades vegetais diminuiu para trezentas. Da década de 50 até hoje as variedades vegetais diminuíram para 34 tipos vegetais sendo que $80 \%$ deste

transgênica, que possivelmente cruzou com sua canola convencional e contaminou sua plantação. Para maiores detalhes verificar: <http: //www.peryschmeiser.com>

12 João Pedro Stédile - Palestra realizada na Jornada de Agroecologia 2004, em Ponta GrossaPR. mai. 2004. 
número é representado por apenas quatro culturas: trigo, soja, milho e feijão.

Logo, é sob tais parâmetros que se pretende analisar a situação do Brasil em relação transgenia já que o país representa um mercado, principalmente da cultura de soja, bastante cobiçado e disputado por tais empresas.

\section{II - O Governo Fernando Henrique Cardoso e a CTNBio}

Nas décadas de 60 e 70 no Brasil ocorreu um processo chamado de "Revolução Verde" que se caracterizou pela intensificação da industrialização e da urbanização no país. O meio agrícola teve sua produção incrementada por maquinários e novas tecnologias de plantio, a inserção maciça de agrotóxicos também ocorre nestas duas décadas. É neste período que as questões ambientais começam a despertar o interesse dos Estados e das sociedades já que os reflexos da degradação ambiental eram cada vez mais aparentes. Desta forma tais preocupações materializam-se na conferência de Estocolmo em 1972, contudo é apenas em 1988 que a Comissão Mundial sobre Meio Ambiente e Desenvolvimento das Nações Unidas publica um documento intitulado Nosso Futuro Comum ${ }^{13}$ que consolida a preocupação de sustentabilidade ${ }^{14}$ ambiental no âmbito internacional. Entretanto, como sugere Leff (2002), apesar do Informe Bruntland ter oferecido uma nova perspectiva à discussão da temática ambiental, não há o questionamento a respeito da capacidade de internalização, por parte do sistema econômico, das condições que embasam o conceito de sustentabilidade. Leff (2002) critica a apropriação do conceito de desenvolvimento sustentável pelos defensores do neoliberalismo na medida em que estes defendem que o desenvolvimento do sistema capitalista, através do livre mercado, seria capaz de absorver e solucionar os problemas de ordem ambiental. Para Leis (1996) a maior significação da Rio-92 não se dá no plano político, mas no plano da intersubjetividade, isto é, a percepção da necessidade de visualização das relações sociais e estatais como o aflorar de uma consciência cooperativa.

$\mathrm{O}$ Informe Bruntland teve como passo seguinte a realização da Conferência das Nações Unidas sobre Meio Ambiente e Desenvolvimento

\footnotetext{
${ }^{13}$ Conhecido também como Informe Bruntland.

14 "O desenvolvimento sustentável foi definido como 'um processo que permite satisfazer as necessidades da população atual sem comprometer a capacidade de atender as futuras geraçðes"'. (Leff, 2002, p.19)
} 
no Rio de Janeiro em 1992 (Rio-92) ${ }^{15}$. Nesta conferência houve a elaboração da Agenda 21, que consiste em uma carta de princípios que forma as bases mundiais para o desenvolvimento e respeito ao meio ambiente por todos os Estados do mundo.

Influenciado pela grande repercussão da Rio-92 e pelo crescimento das preocupações a respeito do desenvolvimento e do interesse da transgenia demonstrado por muitos paises, o governo brasileiro cria, três anos após a conferência, a lei de Biossegurança ${ }^{16}$. Esta lei estabelece, pela primeira vez no pais, normas para o uso da engenharia genética no tocante à construção, cultivo, manipulação, comercialização e transporte de Organismos Geneticamente Modificados (OGM ou transgênicos).

A partir das necessidades explicitadas pela Lei de Biossegurança, foi criado um decreto ${ }^{17}$ no mesmo ano, que discorre sobre a criação da Comissão Técnica Nacional de Biossegurança (CTNBio), cujo objetivo principal era de analisar a implementação de uma política de biossegurança no país, tornando-se um órgão oficial do Governo responsável pelo pronunciamento nacional a respeito da viabilidade de transgênicos no Brasil. Vigna (2001) delimita as principais funções da CTNBio previstas no decreto:

A CTNBio tem a finalidade de prestar apoio técnico, consultivo e de assessoramento ao Governo Federal na formulação, atualização e implementação da Política Nacional de Biossegurança relativa à OGM, bem como no estabelecimento de normas técnicas de segurança e pareceres técnicos conclusivos referentes à proteção da saúde humana, dos organismos vivos e do meio ambiente, para atividades que envolvam a construção, experimentação, cultivo, manipulação, transporte, comercialização, consumo, armazenamento, liberação e descarte de OGMs e derivados". (Vigna, 2001, p.03)

Neste período de tramitação legislativa os grandes conglomerados internacionais demonstravam interesse no cenário político brasileiro, e a criação da CTNBio foi um facilitador na instalação destas empresas no Brasil. No governo Fernando Henrique Cardoso houve o primeiro pedido

\footnotetext{
${ }^{15}$ A escolha do Rio de Janeiro como sede da conferência das Nações Unidas se deu porquê no período de discussão da sede onde se realizaria o evento, o Instituto Nacional de Pesquisas Espaciais (INPE) divulgou dados sobre o desmatamento na Amazônia, e a morte de Chico Mendes. (Feldmann, 2003)

${ }^{16}$ Lei $n^{\circ} 8974 / 95$.

${ }^{17}$ Decreto $n^{\circ} 1752 / 95$.
} 
oficial de liberação de transgênicos por parte da empresa Monsanto que, em junho de 1998, pede a liberação de sua soja Roundup Ready para venda no mercado brasileiro.

Tendo em vista a ameaça da possibilidade da inserção de transgênicos no país, várias instituições representantes da sociedade civil, principalmente a Organização não-governamental Greenpeace, o Instituto de Defesa do Consumidor (IDEC) e a Sociedade Brasileira para o Progresso da Ciência (SBPC) impetram em 1998 uma ação na justiça contra o pedido da Monsanto e conseguem um liminar que impede o cultivo comercial de soja transgênica no país. Estes grupos conseguiram a liminar por demonstrar que a liberação de transgênicos não estaria de acordo com a necessidade de um estudo e um relatório de impacto ambiental (EIA/RIMA) desta tecnologia em obediência ao Princípio de Precaução ${ }^{18}$ presente na legislação brasileira, inclusive na Constituição Federal. Esta batalha judicial rendeu muitas discordâncias no governo. Um exemplo disto é que o Ibama, em fevereiro de 1999, ingressa na ação pública movida pelo IDEC e Greenpeace, entretanto em julho de 2000 retira-se do processo judicial por pressões do governo ${ }^{19}$.

Neste ínterim, entre as decisões e indecisões do Governo, várias plantações experimentais foram liberadas no país já que a liberação destas plantações estaria de acordo com a lei de Biosségurança brasileira e com o sentido de precaução estabelecido pelo EIA/RIMA:

(...) o Judiciário suspendeu o cultivo, em escala comercial, da soja Roundup Ready, do grupo Monsanto, até que fosse apresentado o estudo conclusivo de impacto ambiental. Enquanto não se conclui o estudo, o plantio da soja transgênica fica restrito ao necessário para a realização de testes e do próprio EIA/RIMA, em regime monitorado e em área de contenção, delimitada e demarcada, com a proibição de serem comercializados os frutos obtidos com os aludidos testes. (Vigna, 2001, p.04)

Vigna (2001) apresenta dados que revelam que a permissão de campos experimentais de cultivos transgênicos no país trouxe um grande problema de ordem técnica a partir da falta de cuidado apresentada pelo

\footnotetext{
${ }^{18}$ Este princípio, presente na Agenda 21 e internalizado na legislação brasileira, trata sobre a necessidade de estudos prévios que antecipem a inserção no meio ambiente de métodos que possam vir a trazer problemas e representar riscos para a sociedade e para o meio ambiente.

${ }_{19}$ Para uma melhor visualização da cronologia de acontecimentos referentes a trasngenia no âmbito brasileiro e internacional consultar o seguinte trabalho: Menasche (2003).
} 
governo Fernando Henrique Cardoso. O problema surgiu na medida em que o número de campos experimentais liberados não foi acompanhado pela quantidade de fiscais disponíveis do IBAMA, que havia sido designado como órgão responsável pela vistoria dos campos experimentais ${ }^{20}$. Tal processo facilitou a expansão das plantações para além da área estabelecida. Vigna (2001) relata que os experimentos entre 1997 e 2001 estavam sendo realizados em 12 estados do Brasil, ocupando uma área total de 942,88 hectares. É interessante perceber que $95,17 \%$ da totalidade de áreas liberadas para cultivo experimental de transgênicos em 2001 foram destinada ao grupo Monsanto; a empresa que ficou em segundo lugar neste ranking, com $2,09 \%$, foi a Novartis ${ }^{2 !}$.

Um contra-senso deste processo foi a edição do decreto $\mathrm{n}^{\circ} 3.871$ em junho de 2001 que estabelece a necessidade rotulagem de produtos transgênicos no Brasil. Ao mesmo tempo em que é compreensível que tal decreto vise a rotulagem dos produtos importados respeitando o direito do consumidor, não haveria motivo de se criar um decreto de rotulagem que abrangesse produtos nacionais em um país onde os transgênicos até então eram considerados ilegais.

Ao mesmo tempo em que estas liberações inadequadas ocorriam, uma grande quantidade de soja transgênica estava sendo contrabandeada da Argentina através de sua fronteira com o Rio Grande do Sul. A Argentina é um dos maiores produtores de soja transgênica do mundo, já que $90 \%$ das plantações de soja do país são geneticamente modificadas. Este contrabando ocorreu por dois motivos principais: primeiro porquê os agricultores obtinham as sementes contrabandeadas a um preço razoavelmente inferior em relação às sementes convencionais oferecidas no mercado brasileiro e, segundo porquê apostaram na divulgação de que as sementes transgênicas seriam mais produtivas que as convencionais.

Um estudo realizado por Nodari e Destro (2002) na região de Palmeira das Missões no Rio Grande do Sul, que versa sobre a baixa porcentagem de germinação de sementes supostamente transgênicas plantadas na região, desmistifica a idéia de que a produtividade das sementes transgênicas contrabandeadas seria maior do que as convencionais. O problema detectado foi que as sementes provindas da Argentina, por serem criadas visando a adaptação em solo argentino, não

\footnotetext{
${ }^{20}$ A designação do IBAMA como responsável pela fiscalização dos campos experimentais de transgênicos foi definida através da liminar n¹0329-01.

21 Dados retirados de um gráfico elaborado pelo Greenpeace. Disponivel em: $<\mathrm{http:}$ //www.greenpeace.org.br> Acesso em: 04 mar. 2001.
} 
produziram o esperado pelos agricultores de Palmeira das Missões. Nodari e Destro (2002) relatam que a diferença de latitude da Argentina e da região riograndense foi a responsável pelos problemas de germinação encontrados:

Os cultivares de soja transgênicos (...) desenvolvidos na Argentina e avaliados em cinco lavouras apresentam altura da planta de aproximadamente $50 \mathrm{~cm}$. Isto evidencia que estes cultivares não são adaptados ao Rio Grande do Sul. Portanto, o seu cultivo acarreta enormes perdas de produtividade aos produtores rurais, por não serem adaptadas às condições climáticas da região. Esta baixa estatura é um indício de que de fato se trata de cultivares desenvolvidas para regiões de maior latitude, Argentina no caso. Assim, quando cultivadas em latitudes menores (neste caso RS, mais ao norte), como o comprimento do dia no periodo de cultivo é menor, as plantas respondem a este sinal e entram em floração mais precocemente do que se estivessem sendo cultivadas em locais cuja quantidade de horas de luz fosse maior (Argentina).

Os dois mandatos de Fernando Henrique Cardoso foram caracterizados pela falta de cuidado com as questões de biossegurança e, ao mesmo tempo, uma enorme indefinição em relação aos transgênicos no país. O contrabando de sementes transgênicas não foi controlado, e Lula ascende ao poder em meio ao grande impasse deixado pelo governo anterior.

\section{III - O Governo Lula e as Medidas Provisórias n¹13 e nº 131}

Quando Lula assume a posse da presidência da República, deparase com uma situação de extrema indefinição e morosidade de decisões. Com o início do governo Lula, os movimentos ambientalistas e sociais comemoraram por acreditarem que este governo levaria em consideração seus apelos e suas causas. Entretanto aqueles que há muitos anos vinham lutando a favor do fortalecimento da legislação ambiental e de biossegurança brasileira sofreram uma grande decepção com a edição de uma medida provisória logo no final de março de 2003.

Esta medida provisória de $\mathrm{n}^{\circ} 113$, que em junho do mesmo ano tornou-se $1 \mathrm{ei}^{22}$, permitiu a legalização temporária da transgenia para poder escoar a safra 2002/2003 de soja, especialmente a transgênica, entretanto

\footnotetext{
${ }^{22}$ A Medida Provisória $n^{\circ} 113$ de 26 de março de 2003 foi convertida na Lei $n^{\circ} 10.688$ em 13 de junho do mesmo ano.
} 
deixa claro em seu texto que na safra seguinte não seriam mais válidas as regras estabelecidas pela $\mathrm{MP}^{23}$. Esta medida provisória foi motivo de muitas críticas, pois acabou por, temporariamente, "legalizar o ilegal", fato que foi extremamente condenado já que demonstrou a sujeição do governo em relação ao lobby de grupos de interesses tais como os conglomerados internacionais e a bancada ruralista do governo. Araújo (2003) acredita que esta medida provisória, ao dar solução para a ilegalidade e para o ato ilícito realizado pelos agricultores que plantaram transgênicos, "corrobora os sentimentos de impunidade e de desmoralização das normas e contraria as supostas intenções de moralidade e de atenção aos interesses maiores da sociedade, bem assim o apreço ao Princípio da Precaução, presentes no programa do governo". (Araújo, 2003, p.03).

A edição desta medida provisória não resolveu em absoluto a problemática referente aos transgênicos no país, apenas permitiu que a impunidade fosse institucionalizada; fruto disso foi a edição, em setembro do mesmo ano, de mais uma medida provisória, de $\mathrm{n}^{\circ} 131^{24}$, que liberou a venda da safra seguinte $(2003 / 2004)$ novamente afirmando que a medida tratava exclusivamente da liberação daquela safra; portanto, tais regrais não seriam válidas para a safra seguinte.

A ministra Marina Silva propôs como alternativa ao impasse que as safras contaminadas com transgênicos fossem escoadas e vendidas no mercado externo, entretanto tal proposta foi recusada pelo governo que também liberou a venda interna dos grãos produzidos.

\section{Conclusão:}

Os movimentos da sociedade civil e os ambientalistas sofreram grande decepção com a forma paliativa de atuação do governo em relação aos transgênicos. Atualmente muitos agricultores, por ignorância, ambição ou ingenuidade, estão vinculados a empresas multinacionais através de contratos e de pagamento de royalties.

Não posso deixar de comentar uma situação que me causou bastante aflição quando participei da Jornada de Agroecologia de 2004 em Ponta Grossa. Neste evento várias palestras e oficinas de temáticas diversas ocorreram (oficinas de cultura, agrotóxicos, políticas públicas, transgênicos,

\footnotetext{
${ }^{23}$ A medida provisória previa a incineração do estoque existente após a data definida para o escoamento da safra pelo governo, e ainda provia multas de mais de 16 mil reais para os que infringissem a lei.

${ }^{24}$ Convertida posteriormente na Lei $\mathrm{n}^{\circ} 10814 / 03$.
} 
orgânicos, etc). Tive o prazer de participar da oficina sobre transgênicos e lá ouvir o depoimento de um agricultor assentado do MST no Rio Grande do Sul que demonstrou em seu discurso a injustiça que ocorre com aqueles que ainda tentam plantar soja convencional na região. $\mathrm{O}$ agricultor relatou que assim que a safra era colhida, todos tinham que declarar se sua soja era convencional ou transgênica. Desta forma, a soja, quando depositada nas cooperativas, passava por um teste de comprovação. Caso na declaração constasse que a soja era transgênica e o teste detectasse transgênicos o agricultor tinha que pagar $\mathrm{R} \$ 0,60$ por saca de soja (que representariam os royalties das empresas). Entretanto se o agricultor declarasse sua soja como convencional e o teste detectasse transgênicos, além de pagar $\mathrm{R} \$ 1,50$ por saca de soja, o agricultor tinha que pagar uma multa para a empresa fornecedora da semente transgênica e para a cooperativa da qual faz parte.

O grande problema é que por falta de conhecimento dos agricultores, os responsáveis pelos testes mesmo obtendo o resultado de soja convencional, fraudavam o teste dizendo que havia sido detectado transgênicos. Os agricultores assustados pagavam, e com medo de ocorrer o mesmo na safra seguinte começavam a plantar transgênicos.

Logo, a internalização de transgênicos no país trouxe um problema de ordem estrutural. A lógica de concentração do capital permite a oligopolização de mercado de forma cada vez mais acentuada por parte das empresas transnacionais. Os agricultores, por mais que tenham a liberdade de escolha do que vão plantar, além de sofrerem coerções como a relatada acima, têm seu poder de escolha reduzido na medida em que poucas empresas dominam o mercado de sementes. A edição destas duas medidas provisórias tornou uma situação mal resolvida em um problema ainda maior. A transgenia já está instaurada e agora não há como proibir novamente o plantio e a venda destas sementes no país, apenas há formas de restringir e controlar os que plantam, além de realmente fazer valer a rotulagem de produtos que contém transgênicos para que seja respeitado o direito daqueles que não querem comer alimentos com transgênicos.

Está em tramitação no Senado um projeto de lei de Biossegurança que pretende regulamentar e alterar disposições da antiga lei. Este projeto de lei, antes de ser levado ao plenário deverá ser analisado por quatro comissões (Educação, Constituição e Justiça, Assuntos Econômicos e Assuntos Sociais). O projeto enfrenta uma grande briga entre ministérios já que reforça a necessidade de estudos e relatório de impacto ambiental.

Os transgênicos no Brasil merecem um olhar atento do observador. Muitos dos acontecimentos relatados neste trabalho são certamente 
revoltantes, e para que a revolta não se torne uma página em branco de uma longa história, a situação dos transgênicos neste país deve estar na pauta das discussões acadêmicas e em nossos círculos pessoais para que possamos tornar esta temática facilmente compreensível, e quem sabe criticável.

\section{Referências Bibliográficas:}

ARAGÃO, F.J.L. Organismos Transgênicos. São Paulo: Manole, 2003. ARAÚJO, J.C de. Análise da Medida Provisória $n^{\circ} 113$, de 25 de setembro de 2003. Consultoria Legislativa: Estudo Técnico Específico, 29 set. 2003. Documento 2003.4699.032.

BRASIL, Decreto-lei $n^{\circ} 1752$, de $2^{\circ}$ de dezembro de 1995. Regulamenta a Lei no. 8.974, de 05 de janeiro de 1995, dispõe sobre a vinculação, competência e composição da Comissão Técnica Nacional de Biossegurança - CTNBio, e dá outras providências. Diário Oficial da República Federativa do Brasil, Brasília, p.21648, 21 dez. 1995, Seção I.

BRASIL, Lei $\mathrm{n}^{\circ} 8.974$ de 05 de janeiro de 1995. Regulamenta os incisos II e $\mathrm{V}$ do $\S 1^{\circ}$ do art. 225 da Constituição Federal, estabelece normas para o uso das técnicas de engenharia genética e liberação no meio ambiente de organismos geneticamente modificados, autoriza o Poder Executivo a criar, no âmbito da Presidência da República, a Comissão Técnica Nacional de Biossegurança e dá outras providências. Diário Oficial da República Federativa do Brasil, Brasília, p.337, 06 jan. 1995, Seção I.

CHESNAIS, F. Capitalismo de Fim de Século. In: Coggiola, O. (org.), Globalização e Socialismo. São Paulo: Xamã, 1997.

FELDMANN, F. O mundo dos negócios e o meio ambiente no século 21. In: Trigueiro, A. (coord.), Meio Ambiente no século 21: 21 especialistas falam da questão ambiental nas suas áreas de conhecimento. Rio de Janeiro: Sextante, 2003.

FIORILLO, C.A. Curso de Direito Ambiental Brasileiro. 3.ed. São Paulo: Saraiva, 2002.

HATHAWAY, D. Transgênicos, um salto no escuro? Revista Caros Amigos. n55, out. 2001.

LEFF, E. Saber Ambiental: Sustentabilidade, Racionalidade, Complexidade. Poder. 2.ed. Petrópolis: Vozes, 2001.

LEIS, H. R. O Labirinto: ensaios sobre ambientalismo e globalização. São Paulo: Gaia; Blumenau, SC: Fundação Universidade de Blumenau, 1996. LONDRES, F. Com Bom Senso e Sem Transgênicos. Revista Caros Amigos, São Paulo, dez. 2002. 
MAIRESSE, L. A. Organismos Geneticamente Modificados e a Revolução da Biotecnologia. Seminário Plantas Transgênicas. Santa Maria: UFSM, 2001 .

MENASCHE, R. Os grãos da discórdia e o risco à mesa: um estudo antropológico das representações sociais sobre cultivos e alimentos transgênicos no Rio Grande do Sul. Tese (doutorado) - Universidade Federal do Rio Grande do Sul. Instituto de Filosofia e Ciências Humanas. Programa de Pós-Graduação em Antropologia Social, Porto Alegre, BR-RS, 2003.

MOONEY, P.R. O Século 21: Erosão,Transformação Tecnológica e Concentração do Poder Empresarial. São Paulo: Expressão Popular, 2002.

NODARI, O; DESTRO, D. Relatório sobre a situação de lavouras de soja na região de Palmeira das Missões (RS) - Safra 2001/2002 - Cultivadas com cultivares convencionais e com cultivares transgênicas. La Via Campesina, 2002.

PELAEZ, V; SCHIMIDT, W. A difusão dos OGM no Brasil: imposição e resistências. Estudos Sociedade e Agricultura, n 14 abr. 2000.

PERRIÈRE, R. A. B; SEURET, F. Transgênicos - Uma Ameaça à Agricultura. São Paulo, Vozes, 2003.

RIFKIN, J. O Século da Biotecnologia. São Paulo: Makron Books, 1999. STÉDILE, J.P. - Palestra realizada na Jornada de Agroecologia 2004, em Ponta Grossa-PR. mai. 2004.

VIGNA, E. A Farra dos Transgênicos. Brasilia: Instituto de Estudos Econômicos. 2001. 